\title{
Onset of Aegean-style extensional deformation in the contractional southern Dinarides documented by incipient normal fault scarps in Montenegro
}

Peter Biermanns ${ }^{1}$, Benjamin Schmitz ${ }^{2}$, Silke Mechernich ${ }^{3}$, Christopher Weismüller ${ }^{1}$, Kujtim Onuzi ${ }^{4}$, 5 Kamil Ustaszewski $^{4}$, Klaus Reicherter ${ }^{1}$

${ }^{1}$ Institute of Neotectonics and Natural Hazards, RWTH Aachen University, 52064 Aachen, Germany

${ }^{2}$ Institute of Geosciences, University Jena, 07749 Jena, Germany

${ }^{3}$ Institute of Geology and Mineralogy, University Cologne, 50937 Köln, Germany

${ }^{4}$ Institute of Geosciences, Energy, Water and Environment, Polytechnic University of Tirana, 1016 Tirana, Albania

10 Correspondence to: Peter Biermanns (p.biermanns@nug.rwth-aachen.de)

\begin{abstract}
We describe two previously unreported, 5-7 km long normal fault scarps (NFS) occurring atop fault-related anticlines in the coastal ranges of the Dinarides fold-and-thrust belt in southern Montenegro, a region under predominant contraction. Both NFS show well-exposed, 6-9 m high, striated and locally polished fault surfaces in limestones, documenting active faulting during the Holocene. Sharply delimited ribbons on free rock faces show different color, varying karstification and lichen growth and suggest stepwise footwall exhumation, typical of repeated normal faulting earthquake events. Displacements, surface rupture lengths and geometries of the outcropping fault planes imply paleoearthquakes with $\mathrm{M}_{\mathrm{w}} \approx 6 \pm$ 0.5 and slip rates of c. $0.3-0.5 \mathrm{~mm} / \mathrm{yr}$ since the Last Glacial Maximum. Slip rates based on cosmogenic ${ }^{36} \mathrm{Cl}$ data from the scarps are significantly higher: modeling suggests $1.5 \pm 0.1 \mathrm{~mm} / \mathrm{yr}$ and 6-15 cm slip every c. 35-100 yrs, commencing c. $6 \mathrm{kyr}$ ago. The total throw on both NFS - although poorly constrained - is estimated to max. $200 \mathrm{~m}$, and offsets the basal thrust of a

20 regionally important tectonic unit. Both NFS are incipient extensional structures that postdate growth of the fault-related anticlines on top of which they occur. Interestingly, the position of the extensional features agrees with recent geodetic data, suggesting that our study area is located exactly at the transition from NE-SW-directed shortening in the northwest to NE-SWdirected extension to the southeast. While the contraction reflects ongoing Adria-Europe convergence taken up along the frontal portions of the Dinarides, the incipient extensional structures might be induced by rollback of the Hellenic slab in the

25 SE, whose effects on the upper plate appear to be migrating along-strike the Hellenides towards the northwest. The newly found NFS provide evidence for a kinematic change of a thrust belt segment over time. Alternatively, the NFS might be regarded as second-order features accommodating changes in dip of the underlying first-order thrust faults to which they are tied genetically.
\end{abstract}


https://doi.org/10.5194/se-2021-97

Preprint. Discussion started: 6 August 2021

(c) Author(s) 2021. CC BY 4.0 License.

(c) (i)

\section{Introduction}

30 Active normal faults in the Mediterranean frequently develop bedrock normal fault scarps (NFS). Their suitability as tools for paleoseismic analyses has been proven by many authors (e.g., Armijo et al., 1992; McCalpin, 1996; Benedetti et al., 2002; Papanikolaou et al., 2005, 2013; Grützner et al., 2013, 2016; Mason et al., 2016, 2017; Mechernich et al., 2018). We report two previously unreported, 5-7 km long NFS along the southwestern slopes of the Rumija mountains in the coastal ranges of the Dinarides fold-and-thrust belt in southern Montenegro on the western Balkan Peninsula (Figs. 1 - 4; Figs. S1 \& S2, Table

35 S3). According to their positions between the eponymous towns, we refer to them as Bar (BFS) and Katërkolle (KFS) fault scarps. Both NFS closely resemble the abundant and well-studied NFS in the Central Apennines (Italy; e.g., those ruptured during the 2016/2017 earthquake series) as well as in the Greek part of the Hellenides in terms of structural setup and length, showing evidence of segmentation and repeated co-seismic footwall exhumation during earthquakes (e.g., Papanikolaou et al., 2005, 2013, Grützner et al., 2016; Mason et al., 2016; Civico et al., 2018; Mechernich et al., 2018). As the Italian and Greek examples suggest that the formation of such large-scale NFS is commonly correlated with strong extensional earthquakes, it is puzzling that all known major historic earthquakes between Southern Croatia and Albania (including e.g., Montenegro 1979, $\mathrm{M}_{\mathrm{w}} \approx 7.1$, or Durrës/Albania 2019, $\mathrm{M}_{\mathrm{w}} \approx 6.4$; e.g., Benetatos and Kiratzi, 2006; Papadopoulos et al., 2020) were exclusively contractional (Fig. 1). The facts that (i) the occurrence of these newly discovered extensional structures is still fully unexplained, (ii) similar NFS in Italy and Greece are associated with major earthquakes causing many casualties and severe economic losses from destroyed medieval villages and modern infrastructure (e.g., Chiaraluce et al., 2017, Table S4) and that (iii) smaller fault systems are generally underestimated in terms of their seismic hazard (Grützner et al., 2013), underline the urgent need to analyse such structures. Apart from the seismic hazard perspective, the occurrence of (possibly seismogenic) NFS in a purely contractional segment of a fold-and-thrust belt indicates a possible temporal transition in the kinematic behaviour of a mountain range - a phenomenon rarely documented in detail and calling for a geodynamic explanation.

\section{$50 \quad 2$ Geological setting}

Driver for the seismicity along the coast of Montenegro and Albania is the Adriatic microplate, whose northward motion is accompanied by a bidirectional subduction below the Balkan and Apennine peninsulas, creating almost mirror-imaged tectonic settings on both sides of the Adriatic Sea (e.g., Faccenna et al., 2014; Le Breton et al., 2017; Király et al., 2018). Both, the Apennines and Dinarides-Hellenides fold-and-thrust belts are characterized by orogen-parallel, NW-SE-striking tectonic units.

55 NE-SW-directed contraction along the deformation front is replaced by extensional domains in the hinterland (Fig. 1). The latter is attributed to subduction-rollback, gradually migrating towards Adria in both cases (e.g., Cavinato and de Celles, 1999; Dumurdzanov et al., 2005; Carminati and Doglioni, 2012, Handy et al., 2019). Despite all similarities, seismotectonic characteristics for the concerned areas reveal major differences: In Italy, destructive earthquakes are dominantly within the hinterland extensional domain, whereas in the Dinarides-Hellenides, they are rather contractional, with epicentres close to the Montenegrin/Albanian coast (e.g., Pondrelli et al., 2006; Copley et al., 2009; Chiaraluce et al., 2017; Papadopoulos et al., 
https://doi.org/10.5194/se-2021-97

Preprint. Discussion started: 6 August 2021

(c) Author(s) 2021. CC BY 4.0 License.

(c) (i)

2020; Vittori et al., 2020; Fig. 1). Accordingly, large-scale normal faults are abundant in the extensional Apennines hinterland (e.g., Galadini and Galli, 2000), while they are less prominent in Albania (Handy et al., 2019) and so far unknown in Montenegro. We consider this view obsolete: the two newly reported NFS of Bar and Katërkolle (BFS and KFS; Figs. 2 - 4; Figs. S1 \& S2; Table S3) are not located in the hinterland away from the coast, where extensional focal mechanisms are well documented, but as close as $4 \mathrm{~km}$ from the coast, in a fold-and-thrust belt segment solely characterized by horizontal contraction, evidenced both in the geological structures and in the predominance of reverse faulting focal mechanisms (Fig. 1). Structurally, the BFS and KFS are located in the Budva-Cukali Unit, a regionally important tectonic nappe in the DinaridesHellenides consisting mainly of Mesozoic pelagic sediments topped by Paleogene synorogenic deposits (Fig. 4). In the study area, along the Rumija mountain front, only the uppermost part of its stratigraphic section appears as a c. $50 \mathrm{~m}$ wide corridor

70 between the structurally underlying Dalmatian and the overlying High Karst tectonic units. Furthermore, the Budva-Cukali Unit appears in remnants at the base of the High-Karst Unit in two isolated nappe outliers (Fig. 4). For more detailed information on the regional geology of the area, the reader is referred to, e.g., Biermanns et al., 2019; Schmid et al., 2020; and Schmitz et al., 2020. Current horizontal shortening rates for this region lie in the range of 3-5 mm/yr (Kotzev et al., 2008; Jouanne et al., 2012; Devoti et al., 2017), while vertical uplift rates were estimated to around $1 \mathrm{~mm} / \mathrm{yr}$ (Biermanns et al., 2019 and references therein).

\section{Methods}

\subsection{Fieldwork}

\subsubsection{Structural and morphological mapping, site selection and fault scarp profiling}

The full extent of BFS and KFS was geologically and structurally mapped to gain details of fault morphology and orientation, fault striae, surface roughness and lichen growth (Fig. 4; Figs. S5 - S8). Based on the mapped fault lengths (Table S9) and an evaluation of horizons interpreted to display coseismic displacements per earthquake event (Figs. 3 B and S6, detailly described in section 4.1), we calculated earthquake magnitudes after Wells and Coppersmith (1994). Furthermore, four representative sites (Figs. 4 \& S1; Table S3) were selected to estimate long-term (post-Last Glacial Maximum, LGM) slip rates based on topographic profiles across the fault scarps (Fig. 5, following examples of e.g., Papanikolaou et al., 2005; Mason et al., 2016)

85 and to collect samples for ${ }^{36} \mathrm{Cl}$ dating (see Section 3.2). The four sites fulfil all essential requirements like minimum erosion and deposition, flat scarp base, intact scarp surface and representative striations (e.g., Bubeck et al., 2015; Mechernich et al., 2018). The fault planes were cleared from vegetation (particularly for ${ }^{36} \mathrm{Cl}$ dating, Fig. 6), followed by a thorough structural survey including the immediate surroundings. Profiles were measured by broomstick and clinometer parallel to striations in 1$\mathrm{m}$ steps, c. $50 \mathrm{~m}$ upslope and downslope the NFS. The entire NFS height consists of two sections: (i) height of the distinct free-face and (ii) degraded NFS height, interpolated from hanging wall and footwall slope (Fig. 5). Based on these, we 
https://doi.org/10.5194/se-2021-97

Preprint. Discussion started: 6 August 2021

(c) Author(s) 2021. CC BY 4.0 License.

(c) (i)

calculated two sets of post-LGM (18 $\pm 3 \mathrm{kyr}$ ) movement rates: (i) A conservative one, only considering slip on the visible freeface and (ii) a progressive one, incorporating the degraded NFS in prolongation of the free-face (Table S10).

\subsection{2 ${ }^{36} \mathrm{Cl}$ dating: sampling procedure}

Samples for ${ }^{36} \mathrm{Cl}$ dating were taken at site $\mathrm{BFS}_{\mathrm{N}}$ (introduced in Section 3.1.1; Figs. 3 E \& 6; Table S2). For extraction of datable rock samples, a trace across the highest part of the outcrop wall was defined parallel to the visible striations (Fig. 6 C \& F; q.v. Mechernich et al., 2018). To achieve an adequate resolution for the reconstruction of long-term slip rates and seismic events, we chose a sample spacing of ca. $50 \mathrm{~cm}$ parallel to slip direction whilst avoiding confounding factors (e.g., joints, Fig. 6 F). The lowermost samples were collected ca. $1 \mathrm{~m}$ below the scarp base by manual excavation of a trench (Fig. $6 \mathrm{C}$ ). These buried samples are essential to characterize pre-exposure conditions (e.g., Mechernich et al., 2018). The previously marked 15 x 5 $\mathrm{cm}$ sample blocks were carefully extracted with the help of an angle grinder, hammer and chisel (Fig. 6 D-F). Subsequently they were marked according to their distance from the scarp base and packed for shipping. To quantify the risk of insolation weathering at the sampling sites, exposure angles were determined in $10^{\circ}$ steps with the help of a clinometer.

\section{$3.2{ }^{36} \mathrm{Cl}$ dating: sample preparation and data modelling}

\subsubsection{Sample preparation}

105 Based on a spacing of 100-200 cm (striation-parallel distance on the fault plane), six sample blocks from sampling site $\mathrm{BFS}_{\mathrm{N}}$ were prepared at the Institute of Geology and Mineralogy of the University of Cologne. Weathered parts and pore surroundings were carefully removed with a rotary tool before crushing and sieving. The following chemical treatment and the measurement at the CologneAMS facility were performed as described in Mechernich et al. (2018). Resulting ${ }^{36} \mathrm{Cl} /{ }^{35} \mathrm{Cl},{ }^{36} \mathrm{Cl} /{ }^{37} \mathrm{Cl}$, and ${ }^{35} \mathrm{Cl} /{ }^{37} \mathrm{Cl}$ ratios were used to calculate the concentrations of ${ }^{36} \mathrm{Cl}$ and natural chlorine (Clnat). Their reliability is confirmed by

110 the simultaneous preparation of CoCal- ${ }^{36} \mathrm{Cl}$ standard material (Mechernich et al., 2019) and one blank in the respective batch. The blank subtractions were $0.8-1.7 \%$ (Tab. S11). The calculated ${ }^{36} \mathrm{Cl}$ concentrations of the 6 analysed samples range from $\sim 7 \times 10^{4}$ at/g rock at $0.55 \mathrm{~m}$ below the scarp base to $\sim 2 \times 10^{5}$ at/g rock at a height of $5.8 \mathrm{~m}$ above the scarp base. In general, the concentrations are continuously increasing with fault scarp height (Fig. 7). The natural chlorine concentrations are very low, from 6 to $17 \mu \mathrm{g} / \mathrm{g}$ (Tab. S11). One replicate sample was prepared and measured in Cologne (Tab. S11). An aliquot

115 of each dissolved sample was analysed by in-house ICP-OES at the University of Cologne to determine the concentrations of the principal ${ }^{36} \mathrm{Cl}$ target elements, $\mathrm{Ca}, \mathrm{K}, \mathrm{Ti}$, and Fe. The ICP-OES Ca concentrations of the $\mathrm{BFS}_{\mathrm{N}}$-samples range from $38.9 \%$ to $40.0 \%$, indicating local variabilities (Tab. S13) with a minor impact on the ${ }^{36} \mathrm{Cl}$ production rate. We used one none-treated free-face sample from the $\mathrm{BFS}_{\mathrm{N}}$ site as a reference for the assumed thermal and epithermal neutron flux and thus constrain production of ${ }^{36} \mathrm{Cl}$ on ${ }^{35} \mathrm{Cl}$. Equally, trace element analyses on these sample were used for the ${ }^{36} \mathrm{Cl}$ production estimate (Tab. 
https://doi.org/10.5194/se-2021-97

Preprint. Discussion started: 6 August 2021

(c) Author(s) 2021. CC BY 4.0 License.

120 S13). Both analyses were performed by Actlabs (Canada). For the hanging wall composition, we used the soil composition of the colluvium.

\subsection{2 ${ }^{36} \mathrm{Cl}$ scarp modelling method and parameters}

To determine earthquake ages from the ${ }^{36} \mathrm{Cl}$ concentrations we used the Matlab® code of Schlagenhauf et al. (2010) that models synthetic ${ }^{36} \mathrm{Cl}$ concentrations while accounting for all influencing factors, i.e., the time-dependent variability of the fault scarp geometry, the chemical composition and the respective amount and timing of progressive exhumation. All input parameters are described in the following section and in Tables S11 - S13. Several parameters have an influence on the production of cosmogenic ${ }^{36} \mathrm{Cl}$, which typically extends to several meters to tens of meters below the surface. In addition to the chemical composition and density of the bedrock scarp and colluvial wedge (Tab. S12), the ${ }^{36} \mathrm{Cl}$ production rate depends strongly upon the rate at which the scarp is exhumed. Continuous accumulation of ${ }^{36} \mathrm{Cl}$ in the footwall rock occurs both in the shallow sub-surface (inherited or pre-exposure component) and to the largest part as the scarp becomes sub-aerially exposed and grows higher (e.g., Schlagenhauf et al., 2010; Mechernich et al., 2018). This typically leads to increasing ${ }^{36} \mathrm{Cl}$ concentrations with fault scarp height, although this is somewhat complicated by erosion of the scarp free-face, whereby ${ }^{36} \mathrm{Cl}$ in the rock is reduced by weathering. Furthermore, production rates have to be scaled appropriately to the local and distant shielding of the site from cosmic rays and for changes of production through time due to geomagnetic field effects. In general, large offsets result in a stepwise pattern of ${ }^{36} \mathrm{Cl}$ concentrations (e.g., Schlagenhauf et al., 2010). For the latitude and height of our study side, an offset of at least $\sim 2 \mathrm{~m}$ is required. Hence, the coseismic offsets of $\sim 5-15 \mathrm{~cm}$ as observed from the ribbon mapping (see section 4.1) are significantly too low to generate such stepwise ${ }^{36} \mathrm{Cl}$ pattern. The average density of the limestone samples was determined using the sample weight and their volume by suppression in water yielding $2.55 \mathrm{~g} / \mathrm{cm}^{3}$. The density of the colluvium was estimated at $\sim 1.5 \mathrm{~g} / \mathrm{cm}^{3}$; more specific measurements were not undertaken due to local variabilities in

140 the clast occurrence and humidity impact. We used a ${ }^{36} \mathrm{Cl}$ production rate of $48.8 \pm 3.4 \mathrm{at} / \mathrm{g} / \mathrm{yr}$ from Ca-spallation (Stone et al., $1996)$ as it is derived from a similar latitude $\left(39^{\circ} \mathrm{N}\right)$, a rather comparable altitude (1445 $\mathrm{m}$ a.s.l.) and integrates over a timespan of $17.3 \mathrm{kyr}$, which is appropriate for our postglacial focus. All further production rates used are given in Table S13. Scaling with respect to latitude and elevation was performed using the Stone (2000) scaling scheme assuming a constant geomagnetic field intensity. The geometry of the fault as derived from the topographic profile (Fig. 5) is used to calculate

145 shielding factors for the time-dependent self-shielding during the progressive exhumation of the fault plane. Thereby, $33^{\circ}$ was used for the dip of the hanging wall, $56^{\circ}$ as dip of the fault plane, $35^{\circ}$ as dip of the footwall and $22.2 \mathrm{~m}$ as the total displacement of the hillslope. An additional topographic shielding does not occur since the mountains in sight occur just insignificantly above the horizon. There is a significant local variation in the amount of weathering of the exposed fault plane, ranging from zero at locations of preserved slickensides ( $0-3 \mathrm{~m}$ of the free-face height) to $\sim 3 \mathrm{~cm}$ at the solution flutes. While the fault plane

150 at the scarp base is smooth at a mm-scale, rock surface relief at 8.0-8.8 $\mathrm{m}$ height is 2-8 $\mathrm{mm}$ around the sampling line. Assuming this as the minimum amount of erosion and using a preliminary calculated ${ }^{36} \mathrm{Cl}$ age of $\sim 15 \mathrm{kyr}$ at $8.8 \mathrm{~m}$ height, we estimate an erosion rate of $\sim 1 \mathrm{~mm} / \mathrm{kyr}$ at our sample locations. Such a low rate was also observed on other fault planes in carbonates 
https://doi.org/10.5194/se-2021-97

Preprint. Discussion started: 6 August 2021

(c) Author(s) 2021. CC BY 4.0 License.

\section{(c) (1)}

(Goldberg et al., 2016; Mechernich et al., 2018). The parameters used in the numerical modelling of the ${ }^{36} \mathrm{Cl}$ concentration with the Matlab® code modelscarp.m presented in Schlagenhauf et al. (2010) are displayed in Tab. S14.

\section{Results}

\subsection{Structure and morphology of the fault scarps}

Both, the BFS and KFS crosscut the c. $30^{\circ}$ northeast-dipping beds of the Budva-Cukali tectonic zone at high angles (Figs. 5 \& S5). Bedrock limestone in the footwall is juxtaposed against carbonatic, partly cemented colluvium and slope scree in the hanging wall, consisting of $\mathrm{cm}$ - to m-sized clasts (Figs. $3 \mathrm{~B} \& \mathrm{C}$ ). The fault zone is marked by a cataclastic fault breccia of $\geq 1 \mathrm{~m}$ width (Fig. $3 \mathrm{D}$ ). Fault dip directions, pervasive slickenside striations, slickenfibres, Riedel shears, well-developed triangular facets and wine-glass-shaped valleys (Fig. $3 \mathrm{~A} \& \mathrm{C}$ ) prove active normal faulting. The total throw is estimated to max. $200 \mathrm{~m}$, based on cross sections across KFS (Fig. 4 C). Free-faces are 1-9 $\mathrm{m}$ high in domains with negligible erosion (Figs. $3 \mathrm{E} \& \mathrm{~S} 2 \mathrm{C}$ ), and up to $40 \mathrm{~m}$ in domains of strong hanging wall erosion, e.g., where gullies occur (Fig. $3 \mathrm{~A} \& \mathrm{C}$ ). Fault planes frequently exhibit c. 5-50 cm wide, horizontal and sharply bound ribbons of distinct colour and roughness, increasingly better preserved toward the scarp base (Figs. 3 B \& S6). Widths of karstic solution flutes, roughness, lichen growth and microkarstification decrease stepwise toward the scarp base (Fig. S6). These ribbons are interpreted as single exhumation events (Mechernich et al., 2018 and references therein). The BFS dissects the slopes of Mt. Lisinj (Fig. 2). Approximately midway along its c. 5-km-extent, it significant changes its mean fault plane orientation from moderately steep $\left(\sim 55^{\circ}\right)$ c. NNW-SSE striking in the north, to steep $\left(\sim 70^{\circ}\right)$ c. east-west striking in the south (Figs. 4, S5 and S7 A \& B). Since no conclusive outcrops were found in the transitional area, a connection of the northern $\left(\mathrm{BFS}_{\mathrm{N}}\right)$ and southern $\left(\mathrm{BFS}_{\mathrm{S}}\right)$ section of BFS is not fully provable (Fig. S1 \& S8, Table S3). Ribbon abundance and widths are comparable along the full length of BFS (Fig. S7 A \& B). KFS follows the southern slopes of the Rumija mountains for $>7 \mathrm{~km}$ and crosscuts thrusts at the base and top of the BudvaCukali zone (Fig. 4). A connection between BFS $\mathrm{S}_{\mathrm{S}}$ and KFS is conceivable, as suggested by (i) a similar mean fault plane orientation and (ii) an interjacent penetrative step in terrain steepness (Fig. S8). However, a lack of intermittent outcrops for c. $3 \mathrm{~km}$ along-strike and less abundant ribbons (Fig. S7 C) render such correlation less certain. Along all NFS sections, fault planes reveal systematic undulations and corrugations with wavelengths up to several meters (Fig. $3 \mathrm{C}$ ). The trends of striations follow the mean fault plane orientation, indicating dominant dip-slip kinematics. A tendency to increasing strike-slip components away from the section centres creates patterns of radially outward-diverging striations (Fig. S5).

\subsection{Proxies for fault scarp exhumation}

\subsubsection{Slip rate and magnitude estimates derived from fault scarp profiling, surface rupture lengths and ribbons}

Sets of conservative and progressive slip rates were calculated according to the procedures described in Section 3.1.1. The obtained conservative rates range between $0.34 \pm 0.07$ (site $\mathrm{BFS}_{\mathrm{S}} 2$ ) and $0.49 \pm 0.10$ (site $\mathrm{BFS}_{\mathrm{N}}$ ) $\mathrm{mm} / \mathrm{yr}$. The progressive rates vary between $0.41 \pm 0.08\left(\right.$ site $\left.\mathrm{BFS}_{\mathrm{S}} 2\right)$ and $1.23 \pm 0.25\left(\right.$ site $\left.\mathrm{BFS}_{\mathrm{N}}\right) \mathrm{mm} / \mathrm{yr}$ (Table S10). Measurements of earthquake-related 
https://doi.org/10.5194/se-2021-97

Preprint. Discussion started: 6 August 2021

(c) Author(s) 2021. CC BY 4.0 License.

\section{(c) (i)}

ribbons in a total of 48 sites (Fig. S11) revealed up to five horizons per location, with $15 \mathrm{~cm}$ average and 5-50 cm individual

ribbon width. While the lower ribbons are partly correlatable over longer distances, the higher-up ones are often hardly distinguishable local occurrences. The highest density of single horizons was encountered on $\mathrm{BFS}_{\mathrm{S}}$. An average displacement of $15 \mathrm{~cm} /$ event on a representative free-face (e.g., at site $\mathrm{BFS}_{\mathrm{S}} 1, \approx 6.5 \mathrm{~m}$ high) yields an approximate average recurrence interval of 400 yrs. Magnitude calculations after Wells and Coppersmith (1994) are based on the input parameters (ribbon widths and fault lengths) presented in Table S9. As particularly the connection between different NFS sections and NFS genesis are not trivial, we use different presumptions and calculation methods. Derived magnitudes range from $\mathrm{M}_{\mathrm{w}} \approx 5.3$ to 6.5 .

\subsubsection{Slip rates obtained from ${ }^{36} \mathrm{Cl}$ dating}

Slip rates derived from modelling the ${ }^{36} \mathrm{Cl}$ concentrations on the $\mathrm{BFS}_{\mathrm{N}}$ free-face indicate exceptionally high slip rates of $1.5 \pm 0.1 \mathrm{~mm} / \mathrm{yr}$ for the simplest scenario of a stick-slip behaviour (ca. 6-15 cm slip every ca. 35-100 kyr, Fig. 7) in which the $8.8 \mathrm{~m}$-high free-face was exhumed within the last $5.9 \pm 0.4 \mathrm{kyr}$ (Fig. $7 \mathrm{~B}$ ), without $10 \%$ production rate uncertainty. The according fault scarp age is presumably $14.8+1.0 \mathrm{kyr}$ (Figure $7 \mathrm{~B}$ ). Earthquake ages of $100 \pm 14 \mathrm{yrs}$ (EQ1), $173 \pm 24 \mathrm{yrs}$ (EQ2) and $210 \pm 29 \mathrm{yrs}$ (EQ3) (Fig. 8) were estimated using the mapped coseismic slips of $15 \pm 1 \mathrm{~cm}$ (EQ1), $11 \pm 1 \mathrm{~cm}$ (EQ2) and $5.5 \pm 1 \mathrm{~cm}$ (EQ3). Hence, the earthquake-recurrence interval is around $35-100$ years. Alternative interpretations of the ${ }^{36} \mathrm{Cl}$ data (see Section 5.2) are conceivable but significantly more complicated and hence considered less likely.

\section{Discussion}

\subsection{Reliability of slip rates from fault scarp profiling}

For our classical derivation of slip rates, we assumed that preservation of NFS initiated around the LGM, c. $18 \pm 3$ kyr ago in the Mediterranean region (e.g., Benedetti et al., 2002; Papanikolaou et al., 2005; Giraudi \& Frezzotti,1995). Until then, periglacial conditions allowed slope degrading processes to exceed fault throw rates. Post-LGM warming, waning freeze-thaw cycles and slope stabilization by vegetation allowed fault throw to outpace slope degradation, thus forming pronounced NFS (e.g., Papanikolaou et al., 2005). Estimating slip rates using free-face heights holds two main error sources: (i) The exact timing of LGM and NFS formation onset and (ii) the interpretation of NFS geometry. For our study, (i) is well-constrained by similar studies from Greece and Italy (e.g., Giraudi \& Frezzotti, 1995; Kuhlemann et al., 2009; Papanikolaou et al., 2013). According to Papanikolaou et al. (2005) and references therein, the initiation of NFS formation is shifted to ages $<18 \mathrm{ka}$. This and the fact that parts of the free-faces have been eroded between $\sim 18 \mathrm{ka}$ and today, make our estimates a conservative minimum. The estimation of errors connected to (ii) is more complex and related to both tectonic and erosional impacts. Unknown proportions of the presently degraded fault scarps were formed both pre/syn- and post- LGM. The effect of ongoing (but reduced) erosion after formation of the NFS highly varies for different segments. The KFS and BFS s are south- (i.e., not sea-) facing and better protected by vegetation. Especially for $\mathrm{BFS}_{\mathrm{S}}$, dissection by erosional gullies is minimal. Free-faces are steep and moderately high, degraded scarps less developed and earthquake ribbons well-visible and abundant (Fig. S7 B). By contrast, BFS $\mathrm{N}_{\mathrm{N}}$ is more 
https://doi.org/10.5194/se-2021-97

Preprint. Discussion started: 6 August 2021

(c) Author(s) 2021. CC BY 4.0 License.

\section{(c) (1)}

exposed to weathering (i.e., sea-facing, surrounded by less vegetation) and dissected by numerous gullies (Figs. $3 \&$ S1). Here, more degraded scarps, high, shallowly dipping free-faces and fewer earthquake ribbons are observed (Fig S7 A). We hence consider profiling sites $\mathrm{BFS}_{\mathrm{S}} 1$ and $\mathrm{BFS}_{\mathrm{S}} 2$ to provide the most reliable results. Assuming low amounts of local post-LGM erosion at the selected sites, we favour purely free-face-based rates. A comparison with calculations including the degraded NFS (Table S10) shows that our conservative rates are, if at all, probably only exceeded by minimal amounts.

\subsection{Reliability of slip rates and ages from ${ }^{36} \mathrm{Cl}$ dating}

The applied forward modelling method accounts only for the analytical ${ }^{36} \mathrm{Cl}$ uncertainties and not for the uncertainties of the parameters introduced in Section 3.2.2 and Table S13. Changes of these input parameters would shift the modelled earthquake ages to older or younger values, without changing the relative recurrence interval (e.g., Mechernich et al., 2018). The largest effect of such a parameter change is related to the ${ }^{36} \mathrm{Cl}$ production rates from Ca-spallation or muon capture. A change of these two rates in the frame of published uncertainties would systematically shift all ages and slip rates within $\sim 10 \%$. This shift is included in the age calculations but not in the slip rate calculations. Furthermore, the estimated parameters for the density of the colluvium, the erosion rate, and the apparent pre-exposure duration can cause similar shifts of the calculated ages. Changes in the erosion rate, e.g., using the minimum erosion rate of $0 \mathrm{~mm} / \mathrm{kyr}$ would result in $3 \%$ younger ages at the top of the freeface compared to the used $1 \mathrm{~mm} / \mathrm{kyr}$ which was chosen based on the $2-8 \mathrm{~mm}$ of relief at the top of the free-face. Due to the large degraded part of the fault scarp, the choice of the apparent pre-exposure duration has no impact on the restored slip history of the free-face. In Section 4.2.2, we suppose a stick-slip behaviour of the NFS for the interpretation of our ${ }^{36} \mathrm{Cl}$ data. The data itself would indeed leave a margin for other scenarios, e.g., a landslide/rockfall that exhumed the degraded part of the scarp $\sim 6.5 \mathrm{kyr}$ ago, followed by free-face exhumation (Fig. $7 \mathrm{C} \& \mathrm{D}$ ). However, this is ruled out by the fact that no indicators of landsliding were found in the hanging wall at all. Furthermore, the modelled slip rate for this scenario would be as well very high $(\sim 1.1-1.2 \mathrm{~mm} / \mathrm{yr})$, owing to the clearly increasing ${ }^{36} \mathrm{Cl}$ concentrations with scarp height.

\subsection{Interpretation of ribbons, surface rupture lengths and magnitude estimation}

The attribution of earthquake ribbons to individual events is highly ascertained as they are often correlatable across several locations and many of them show sharp boundaries (Figs. 3 B, S6 \& S7). This excludes gradual or localized exhumation by erosion or gravitational processes and technically qualifies them as input parameters for magnitude calculations after Wells

240 and Coppersmith (1994). Minor error sources are misinterpretations of displacement per event, as ribbons may be defaced and overseen. When using fault lengths as input data for the Wells and Coppersmith (1994) method, incorrect recognition of the actual fault lengths constitutes a similar minor error source (see also Section 4.2.1; Table S9). The most severe error source, however, is the application of the empirical approach itself. For our setting with short fault lengths and relatively low magnitudes (i.e., $M_{w}<6$ ), Wells and Coppersmith (1994) only present limited data so that the adequacy of this statistical method

245 is questionable. Depending on the of the interpretation of our NFS in a per-se contractional setting (see Section 5.4), they may portray magnitudes ranging ca. $1 \mathrm{M}$ below the actual magnitude evoked by the rupture of first order thrust faults. The obtained 
https://doi.org/10.5194/se-2021-97

Preprint. Discussion started: 6 August 2021

(c) Author(s) 2021. CC BY 4.0 License.

(c) (i)

values would therefore advance to magnitudes in the range of the Montenegro 1979 earthquake, which are likelier to produce crustal ruptures of such scale (e.g., McCalpin, 1996).

\subsection{Formation mechanisms of normal fault scarps}

The position of the NFS in the hinge of thrust-related anticlines within the nappe stack of the Dalmatian Unit suggests their possible origin along pre-existing planes of weakness (fold-related longitudinal fractures, e.g., Ramsay and Huber, 1983; Tavani et al., 2015 and references therein). Two hypotheses are invoked to explain the NFS in an area governed by horizontal shortening: (i) The northward-migrating boundary between foreland contraction and hinterland extension, which has increasingly migrated westward since Late Eocene (e.g., Dumurdzanov et al., 2005; Reicherter et al., 2011; Handy et al., 2019). (ii) The activation of normal faults as second-order structures during rupture of subjacent first order thrust faults (e.g., Hicks and Rietbrock, 2015), where strain is partitioned in the upper plate or hanging wall. Recent geodetic studies show that the working area lies in the frontalmost part of the deformation zone right at the tip of a north-westwards propagating line separating hinterland extension from foreland contraction (Figs. $1 \& 9$ B, D’Agostino et al., 2021). Gravitational collapse as a result of potential energy contrasts (sensu Copley et al., 2009) can be ruled out as striations, although diverging outward, are relatively consistent with respect to the undulating but otherwise planar fault planes.

Furthermore, the existence of the described NFS has implications on observed GPS-derived convergence rates: The fault slip rate of $1.5 \mathrm{~mm} / \mathrm{yr}$ along the normal fault plane with a dip of $60^{\circ}$ results in a horizontal extension of $0.75 \mathrm{~mm} / \mathrm{yr}$. In order to achieve the geodetically observed convergence of 3-4 mm/yr, the actual convergence must therefore be $3.75-4.75 \mathrm{~mm} / \mathrm{yr}$ (Fig. 9 D). The accommodation of the total convergence in the coastal area (Fig. 9 C) and the lack of instrumentally recorded extensional earthquakes are strongly supportive of scenario (ii). This is further substantiated by the existence of other recent geomorphological features in the study area such as dry valleys and deflected river channels, which indicate a still predominantly contractional regime (Fig. 10, Biermanns et al., 2019; Schmitz et al., 2020).

\section{Conclusion}

We report two previously unknown, active normal faults with well-preserved bedrock NFS along the contractional front of the southern Dinarides fold and thrust-belt. We propose a tectonic, co-seismic origin of these structures. Relations between fault orientation, striations, earthquake ribbons and surrounding structures suggest that the normal faults are either the result of rollback-induced westward migrating extensional tectonics or more likely second-order features linked to subjacent, higherorder thrusts, capable of triggering earthquakes up to $\mathrm{M}_{\mathrm{w}} \approx 7 \pm 0.5$. Maximum magnitudes on the NFS are expected to reach $\mathrm{M}_{\mathrm{w}} \approx 6 \pm 0.5$. Long-term fault slip rates were estimated from free-face height and height of the degraded scarp, assuming a postLGM age ( $\leq 18 \mathrm{kyr}$ ) of the NFS. Minimum slip-rates based on four selected sites amount to $0.34 \pm 0.1-0.49 \pm 0.1 \mathrm{~mm} / \mathrm{yr}$ and recurrence intervals for major earthquakes are in the range of $\leq 400 \mathrm{yrs}$. Although site selection has a large effect on final estimates, these values appear realistic against the backdrop of available GPS rates and common earthquake magnitudes in the region. The normal faults are exactly located above the "blind" thrust fault and epicentre that was responsible for the $\mathrm{M}_{\mathrm{w}} 7.1$ 
https://doi.org/10.5194/se-2021-97

Preprint. Discussion started: 6 August 2021

(c) Author(s) 2021. CC BY 4.0 License.

(c) (i)

Montenegro 1979 earthquake, and hence suggest a relation. In any case, we regard the NFS as a manifestation of repeated

earthquake activity in the study area.

\section{Author contributionss}

Peter Biermanns: Field work, data processing, methodology, original draft preparation, figure visualisation, coordination of writing and editing process, investigation.

Benjamin Schmitz: Field work, data processing, methodology, review and editing, figure visualisation, investigation.

Silke Mechernich: Field work, laboratory analyses, age modelling, writing, review and editing.

Christopher Weismüller: Field work, data processing, figure visualization.

Kujtim Onuzi: Resources, supervision.

Kamil Ustaszewski: Conceptualisation, supervision, project administration, funding acquisition, review and editing.

Klaus Reicherter: Conceptualisation, supervision, project administration, funding acquisition, review and editing.

\section{Competing interests}

The authors declare that they have no conflict of interest.

\section{Data availabilty}

All essential data that this research article is based on are displayed in the according text, figures and supplementary material.

Further raw data is available from the corresponding author on reasonable request.

\section{Acknowlegdements}

We thank Kristijan Sokol, Martin Đaković and Rosalie Kremser for their help with field work, logistics and data processing. Project ALMOND was financed by Deutsche Forschungsgemeinschaft (project no. 269913092) granted to Klaus Reicherter and Kamil Ustaszewski.

\section{References}

300 Armijo, R., Lyon-Caen, H. and Papanastassiou, D.: East-west extension and Holocene normal-fault scarps in the Hellenic arc, Geology, 20, 491-494, 1992.

Benedetti, L., Finkel, R., Papanastassiou, D., King, G., Armijo, R., Ryerson, F., Farber, D. and Flerit, F.: Post-glacial slip history of the Sparta fault (Greece) determined by $36 \mathrm{Cl}$ cosmogenic dating: Evidence for non-periodic earthquakes, Geophys. Res. Lett., 29 (8), doi: 10.1029/2001GL014510, 2002.

305 Biermanns, P., Schmitz, B., Ustaszewski, K. and Reicherter, K., Tectonic geomorphology and Quaternary landscape development in the Albania - Montenegro border region: An inventory, Geomorphology, 326, 116-131, 2019 
https://doi.org/10.5194/se-2021-97

Preprint. Discussion started: 6 August 2021

(c) Author(s) 2021. CC BY 4.0 License.

(c) (i)

Benetatos, C. and Kiratzi, A.: Finite-fault slip models for the 15 April 1979 (Mw 7.1) Montenegro earthquake and its strongest aftershock of 24 May 1979 (Mw 6.2), Tectonophysics, 421, 129-143, 2006.

Bubeck, A., Wilkinson, M, Roberts, G.P., Cowie, P.A., McCaffrey, K.J.W., Phillips, R. and Sammonds, P.: The tectonic geomorphology of bedrock scarps on active normal faults in the Italian Apennines mapped using combined ground penetrating radar and terrestrial laser scanning, Geomorphology, 237, 38-51, 2015.

Carminati, E. and Doglioni, C.: Alps vs. Apennines: The paradigm of a tectonically asymmetric Earth, Earth Sci. Rev., 112, 67-96, 2012.

Cavinato, G.P. and De Celles, P.G.: Extensional basins in the tectonically bimodal central Apennines fold-thrust belt, Italy: Response to corner flow above a subducting slab in retrograde motion, Geology, 27(10), 955-958, 1999.

Chiaraluce, L. et al.: The 2016 Central Italy Seismic Sequence: A First Look at the Mainshocks, Aftershocks, and Source Models, Seismol. Res. Lett., 88 (3), 757-771, 2017.

Civico, R., Pucci, S., Villani, F., Pizzimenti, L., De Martine, P.M., Nappi, R. and the Open EMERGEO Working group: Surface ruptures following the 30 October $2016 \mathrm{M}_{\mathrm{w}} 6.5$ Norcia earthquake, central Italy, J. Maps, 14(2), 151-160, 2018

Copley, A., Boait, F., Hollingsworth, J., Jackson, J. and McKenzie, D.: Subparallel thrust and normal faulting in Albania and the roles of gravitational potential energy and rheology contrasts in mountain belts, J. Geophys. Res., 114, doi: 10.1029/2008JB005931, 2009.

D’Agostino, N., Avallone, A., Cheloni, D., D’Anastasio, E., Mantenuto, S. and Selvaggi, G.: Active tectonics of the Adriatic region from GPS and earthquake slip vectors, J. Geophys. Res., 113, B12413, doi: 10.1029/2008JB005860, 2008.

Devoti, R., D'Agostino, N., Serpelloni, E., Pietrantonio, G., Riguzzi, F., Avallone, A., Cavaliere, A., Cheloni, D., Cecere, G., D’Ambrosio, C., Falco, L., Selvaggi, G., Métois, M., Esposito, A., Sepe, V., Galvani, A., and Anzidei, M.: A Combined Velocity Field of the Mediterranean Region, Annals of Geophysics, 60 (2), S0217, doi:0210.4401/ag-7059, 2017.

D'Agostino, N., Métois, M., Koci, R., Duni, L., Kuka, N. Ganas, A., Georgiev, I., Jouanne, F., Kaludjerovic, N., Kandić, R., Active crustal deformation and rotations in the southwestern Balkans from continuous GPS measurements, Earth and Planetary Science Letters, Vol. 539, https://doi.org/10.1016/j.epsl.2020.116246, 2020.

Dumurdzanov, N., Serafimovski, T. and Burchfiel, B.C.: Cenozoic tectonics of Macedonia and its relation to the South Balkan extensional regime, Geosphere, 1, 1-22, 2005.

Faccenna, C., Becker, T. W., Auer, L., Billi, A., Boschi, L., Brun, J. P., Capitanio, F. A., Funiciello, F., Horvàth, F., Jolivet, L., Piromallo, C., Royden, L., Rossetti, F., and Serpelloni, E.: Mantle dynamics in the Mediterranean, Reviews of Geophysics, 52 (3), 283-332, 2014.

Galadini, F. and Galli, P.: Active tectonics in the central Apennines (Italy)-input data for seismic hazard assessment, Natural Hazards, 22.3, 225-268, 2000.

Geological Survey of Montenegro: Basic geological map sheet of Yugoslavia 1:100.000, sheet Bar (K34-75), Federal geological Institute, Beograd, 1971.

340 Giraudi, C. and Frezzotti, M.: Paleoseismicity in the Gran Sasso Massif (Abruzzo, Central Italy), Quat. Int., 25, 81-93, 1995. 
https://doi.org/10.5194/se-2021-97

Preprint. Discussion started: 6 August 2021

(c) Author(s) 2021. CC BY 4.0 License.

(c) (i)

Goldberg, R., Siman-Tov, S. and Emmanuel, S.: Weathering resistance of carbonate fault mirrors promotes rupture localization, Geophys. Res. Lett., 43, 3105-3111, 2016.

Grünthal, G., Wahlstrom, R. and Stromeyer, D.: The SHARE European Earthquake Catalogue (SHEEC) for the Time Period 1900-2006 and Its Comparison to the European-Mediterranean Earthquake Catalogue (EMEC), J. Seismol. 17, 1339-1344, 2013.

Grützner, C., Barba, S., Papanikolaou, I. and Pérez-López, R.: Earthquake geology: science, society and critical facilities, Ann. Geophys., 56(6), 2013.

Grützner, C., Schneiderwind, S., Papanikolaou, I., Deligiannakis, G., Pallikarakis, A. and Reicherter, K.: New constraints on extensional tectonics and seismic hazard in northern Attica, Greece: the case of the Milesi Fault, Geophys. J. Int., 204, 180199, 2016.

Handy, M. R., Giese, J., Schmid, S. M., Pleuger, J., Spakman, W., Onuzi, K., and Ustaszewski, K.: Coupled Crust-Mantle Response to Slab Tearing, Bending, and Rollback Along the Dinaride-Hellenide Orogen, Tectonics, 38, 2803-2828, 2019.

Hicks, S. P., and Rietbrock, A.: Seismic slip on an upper-plate normal fault during a large subduction megathrust rupture, Nature Geoscience, 8, 955, 2015.

Hunstad, I., Selvaggi, G., D'Agostino, N., England, P., Clarke, P. and Pierozzi, M.: Geodetic strain in peninsular Italy between 1875 and 2001, Geophys. Res. Lett., 30(4), 2003.

Király, Á., Faccenna, C., and Funiciello, F.: Subduction Zones Interaction Around the Adria Microplate and the Origin of the Apenninic Arc, Tectonics, 37, 3941-3953, https://doi.org/10.1029/2018TC005211, 2018.

Kuhlemann, J., Milivojević, M., Krumrei, I. and Kubik, P.W.: Last glaciation of the Šara range (Balkan peninsula): Increasing dryness from the LGM to the Holocene, Austrian J. Earth Sci., 102, 146-158, 2009.

Le Breton, E. Handy, M.R., Molli, R., Ustaszewski, K.: Post-20 Ma Motion of the Adriatic Plate: New Constraints From Surrounding Orogens and Implications for Crust-Mantle Decoupling. Tectonics, 36, 3135-3154, 2017

Mason, J., Schneiderwind, S., Pallikarakis, A., Wiatr, T., Mechernich, S., Papanikolaou, I. and Reicherter, K.: Fault structure and deformation rates at the Lastros-Sfaka Graben, Crete, Tectonophysics, 683, 216-232, 2016.

McCalpin, J. (ed.): Paleoseismology, Volume 62, Academic Press, 1996

Mechernich, S., Schneiderwind, S., Mason, J., Papanikolaou, I.D., Deligiannakis, G., Pallikarakis, A., Binnie, S.A., Dunai, T.J. and Reicherter, K.: The seismic history of the Pisia fault (eastern Corinth rift, Greece) from fault plane weathering features and cosmogenic 36Cl dating, J. Geophys. Res. Solid Earth, 123, 4266-4284, 2018.

Mechernich, S., Dunai, T.J., Binnie, S.A., Goral, T., Heinze, S., Dewald, A., Schimmelpfennig, I., Keddadouche, K., Aumaître, G., Bourlès, D., Marrero, S., Wilcken, K., Simon, K., Fink, D., Phillips, F.M., Caffee, M.W., Gregory, L.C., Phillips, R., Freemann, S.P.H.T., Shanks, R.P., Sarıkaya, M.A., Pavetich, S., Rugel, G., Merchel, S., Akçar, N., Yesilyurt, S., Ivy-Ochs, S., Vockenhuber, C.: Carbonate and silicate intercomparison materials for cosmogenic ${ }^{36} \mathrm{Cl}$ measurements, Nucl. Inst. Methods Phys. Res., B 455, 250-259, 2019. 
https://doi.org/10.5194/se-2021-97

Preprint. Discussion started: 6 August 2021

(c) Author(s) 2021. CC BY 4.0 License.

(c) (i)

Papadopoulos, G. A., Agalos, A., Carydis, P., Lekkas, E., Mavroulis, S., and Triantafyllou, I.: The 26 November 2019 Mw 6.4 Albania Destructive Earthquake, Seismol. Res. Lett., 91, 3129-3138, 2020.

Papanikolaou, I.D., Roberts, G.P. and Michetti, A.M.: Fault scarps and deformation rates in Lazio-Abruzzo, Central Italy: Comparison between geological fault slip-rate and GPS data, Tectonophysics, 408, 147-176, 2005.

Papanikolaou, I., Roberts, G.P., Deligiannakis, G., Sakellariou, A. and Vassilakis, E.: The Sparta Fault, Southern Greece: From segmentation and tectonic geomorphology to seismic hazard mapping and time dependent probabilities, Tectonophysics, 597, 85-105, 2013.

Pondrelli, S., Salimbeni, S., Ekström, G., Morelli, A., Gasperini, P. and Vannucci, G.: The Italian CMT dataset from 1977 to the present: Phys. Earth Planet. Inter., 159, 286-303, 2006.

Ramsay, J. G. and Huber, M. I.: The techniques of Modern Structural Geology: Volume 2: Folds and Fractures, Academic Press, London, 1983.

Reicherter, K., Hoffmann, N., Lindhorst, K., Krastel, S., Fernández-Steeger, Grützner, C. and Wiatr, T.: Active basins and neotectonics: morphotectonics of the Lake Ohrid Basin (FYROM and Albania), Z. dt. Geowiss., 162 (2), 217-234, 2011.

Schlagenhauf, A., Y. Gaudemer, Y., Benedetti, L., Manighetti, I., Palumbo, L., Schimmelpfennig, I., Finkel, R. and Pou, K.: Using in situ Chlorine-36 cosmonuclide to recover past earthquake histories on limestone normal fault scarps: a reappraisal of methodology and interpretations, Geophys. J. Int., 182, 36-72, 2010.

Schmid, S. M., Fügenschuh, B., Kounov, A., Maţenco, L., Nievergelt, P., Oberhänsli, R., Pleuger, J., Schefer, S., Schuster, R., Tomljenović, B., Ustaszewski, K., and van Hinsbergen, D. J. J.: Tectonic units of the Alpine collision zone between Eastern Alps and western Turkey, Gondwana Research, 78, 308-374, 2020.

Schmitz, B., Biermanns, P., Hinsch, R., Đaković, M., Onuzi, K., Reicherter, K. and Ustaszewski, K.: Ongoing shortening in the Dinarides fold-and-thrust belt: A new structural model of the 1979 (Mw 7.1) Montenegro earthquake epicentral region, J. Struct. Geol., 104192, 2020.

Serpelloni, E., Facenna, C., Spada, G., Dong, D. and Williams, S.D.P.: Vertical GPS ground motion rates in the EuroMediterranean region: New evidence of velocity gradients at different spatial scales along the Nubia-Eurasia plate boundary, J. Geophys. Res. Solid Earth, 118, 6003-6024, 2013.

Stone, J. O., Allan, G. L., Fifeld, L.K. and Cresswell, R. G.: Cosmogenic chlorine-36 from calcium spallation, Geoch. Cosmochim. Acta, 60(4), 679-692, 1996.

Stone, J. O.: Air pressure and cosmogenic isotope production, J. Geophys. Res., 105, 23753 - 23759, 2000.

Tavani, S., Storti, F., Lacombe, O., Corradetti, A., Muñoz, J.A. and Mazzoli, S.: A review of deformation pattern templates in foreland basin systems and fold-and-thrust belts: Implications for the state of stress in the frontal regions of thrust wedges, Earth-Sci. Rev., 141, 82-104, 2015.

405 Vittori, E., Blumetti, A. M., Comerci, V., Di Manna, P., Piccardi, L., Gega, D., and Hoxha, I.: Geological effects and tectonic environment of the 26 November 2019, Mw 6.4 Durres earthquake (Albania), Geophysical Journal International, 225, 1174-1191, 2020. 
https://doi.org/10.5194/se-2021-97

Preprint. Discussion started: 6 August 2021

(c) Author(s) 2021. CC BY 4.0 License.

Wells, D.L. and Coppersmith, K.J.: New empirical relationships among magnitude, rupture length, rupture width, rupture area, and surface displacement, B. Seismol. Soc. Am., 84 (4), 974-1002, 1994.

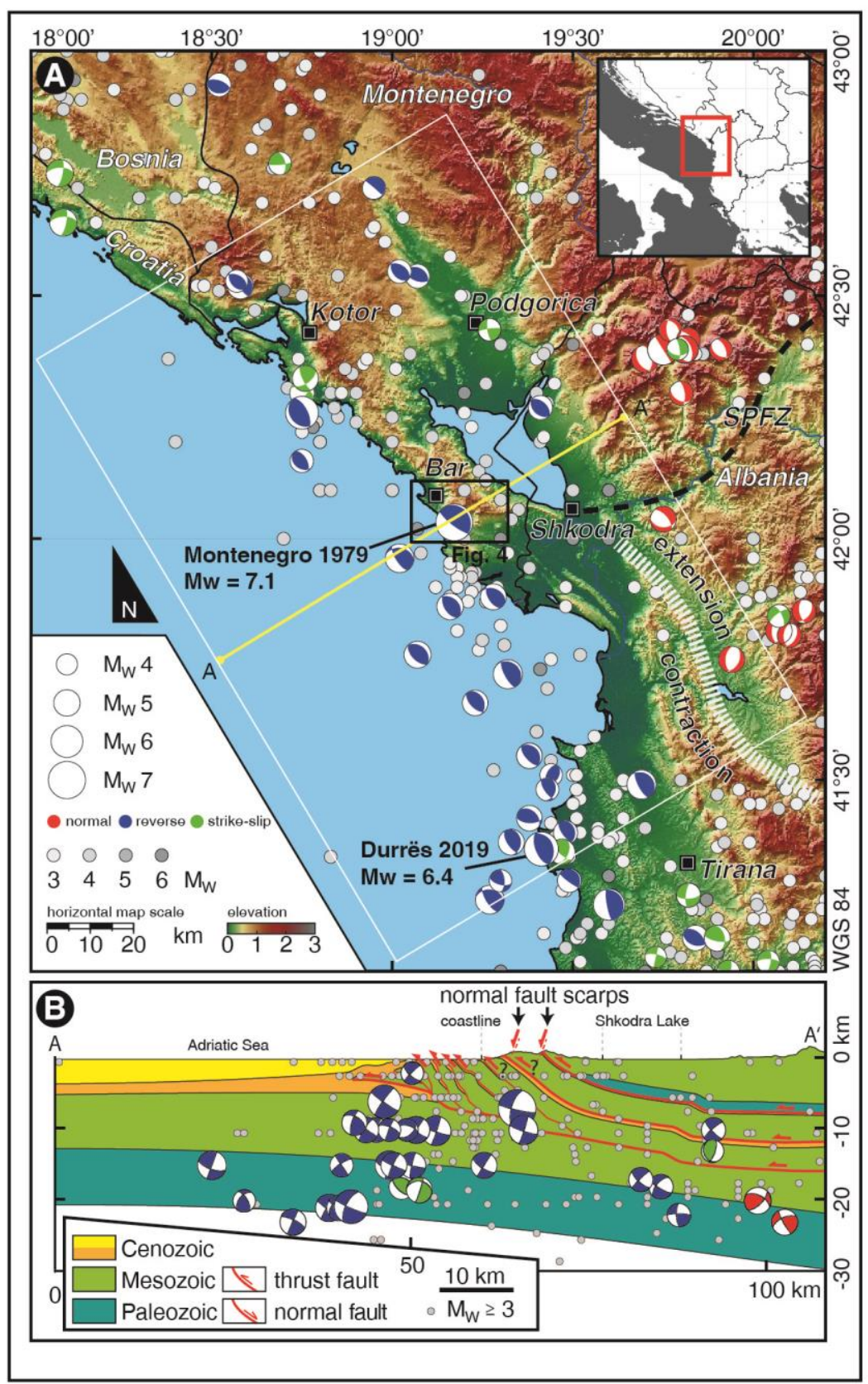

Figure 1: (a) Earthquakes in the study area: Where available, fault plane solutions (FPS) are scaled and color-coded according to magnitude and stress regime. All other earthquakes are color-coded by grey scales according to magnitude. SPFZ=Shkodra-Peja Fault Zone. (b) FPS projected onto Profile A-A' within the range of white box (Fig. 1A). FPS from EMSC, EMRCMT and Harvard catalogues, Pondrelli et al. (2006) and Grünthal et al. (2013). 


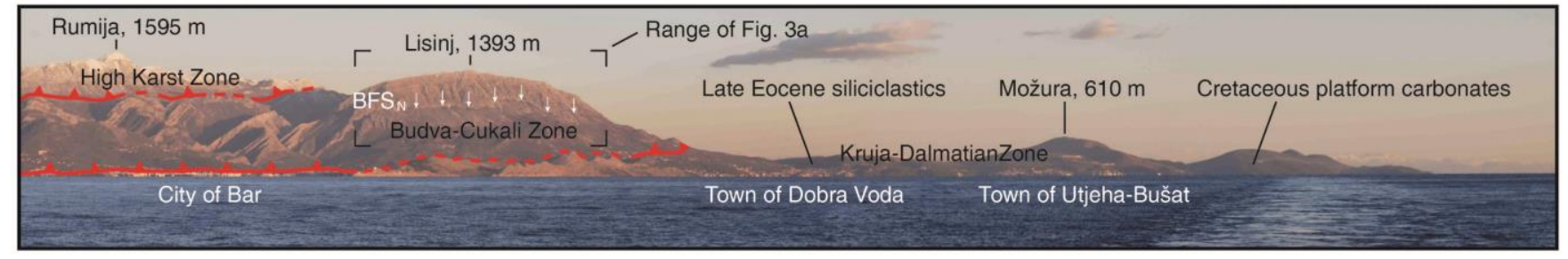

Figure 2: Panoramic view from aboard Meteor research vessel cruise No. 86, leg 3 SE towards the Montenegrin coast, including

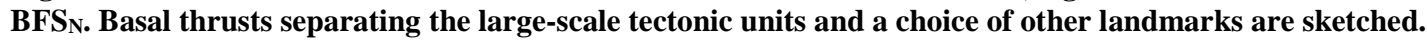
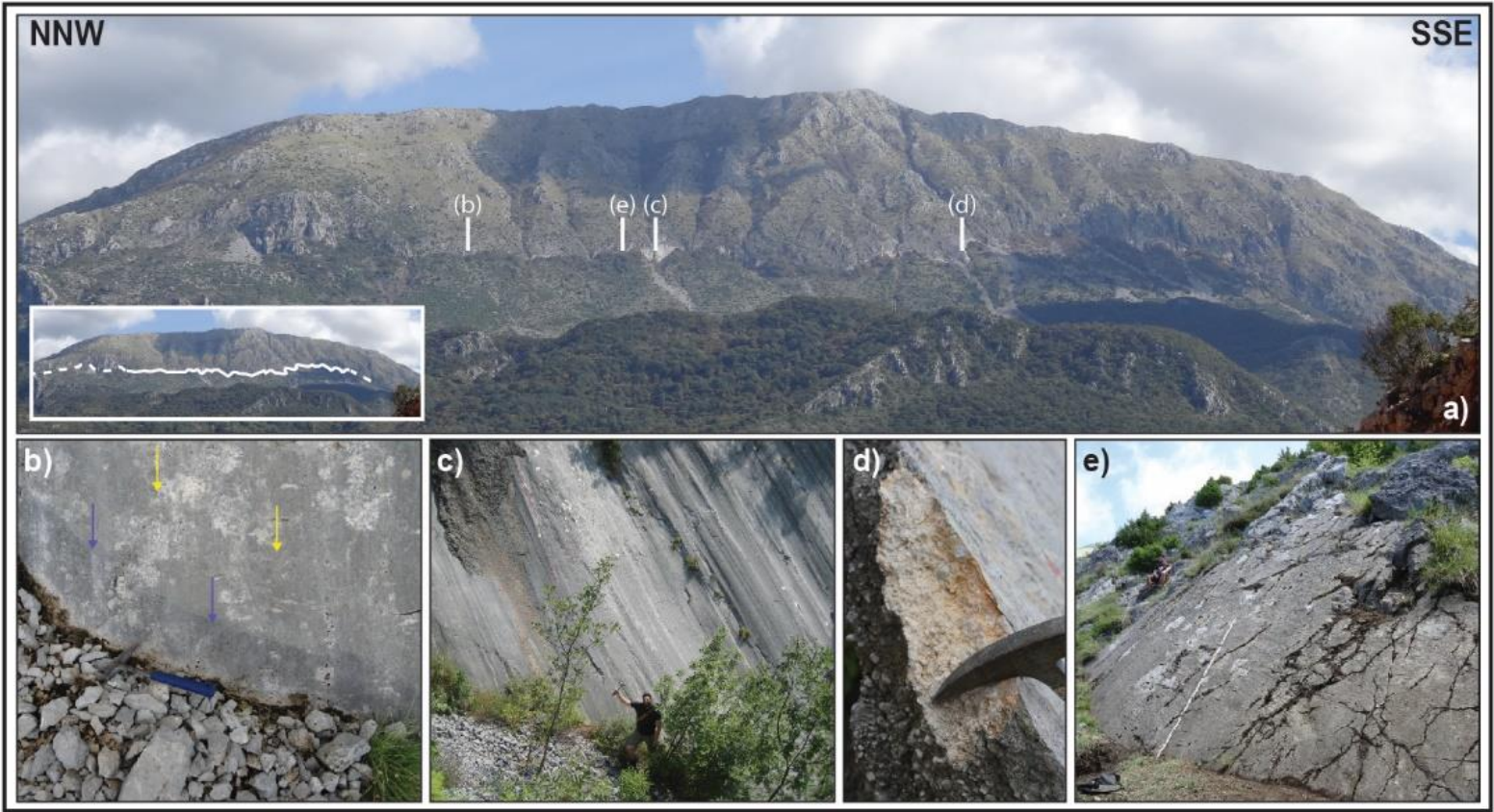

Figure 3: Photographs of the northern section of the Bar fault scarp (BFSN): (A) Panoramic view, fault trace shown in inset. (B) Repeated earthquake ribbons; hammer for scale. Arrows: Blue=young; yellow=older. (C) Fault plane outcrop with characteristic corrugations and oblique-slip lineations; person for scale. (D) Cataclastic fault breccia in the footwall of fault plane; hammer for scale. (E) Sampling site BFS $_{N}$, 2-m ruler for scale; for localization see Fig. 4. 


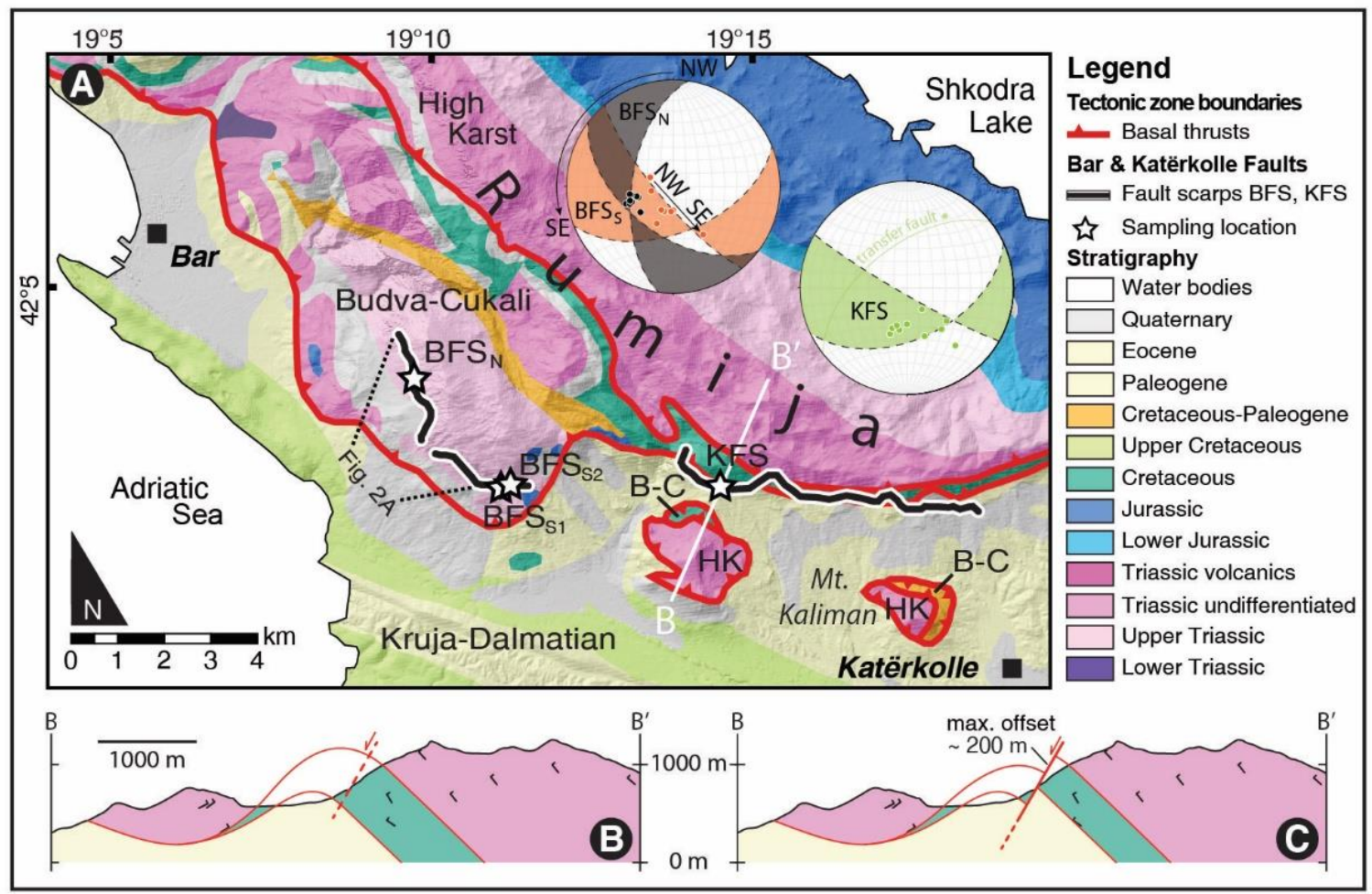

Figure 4: Localization of BFS and KFS on a geological map (Geological map of Yugoslavia, 1971, map sheet Bar - K34-63. Stars

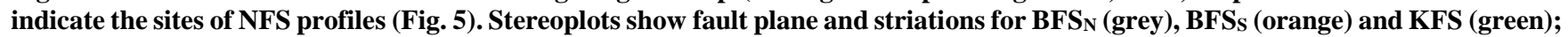
semitransparent coloring: range of plane orientations; dots: mean striations. HK=High Karst, B-C=Budva-Cukali. Bottom: Profile series across KFS indicating maximum offset by NFS; modified from Schmitz et al. (2020). 
https://doi.org/10.5194/se-2021-97

Preprint. Discussion started: 6 August 2021

(c) Author(s) 2021. CC BY 4.0 License.

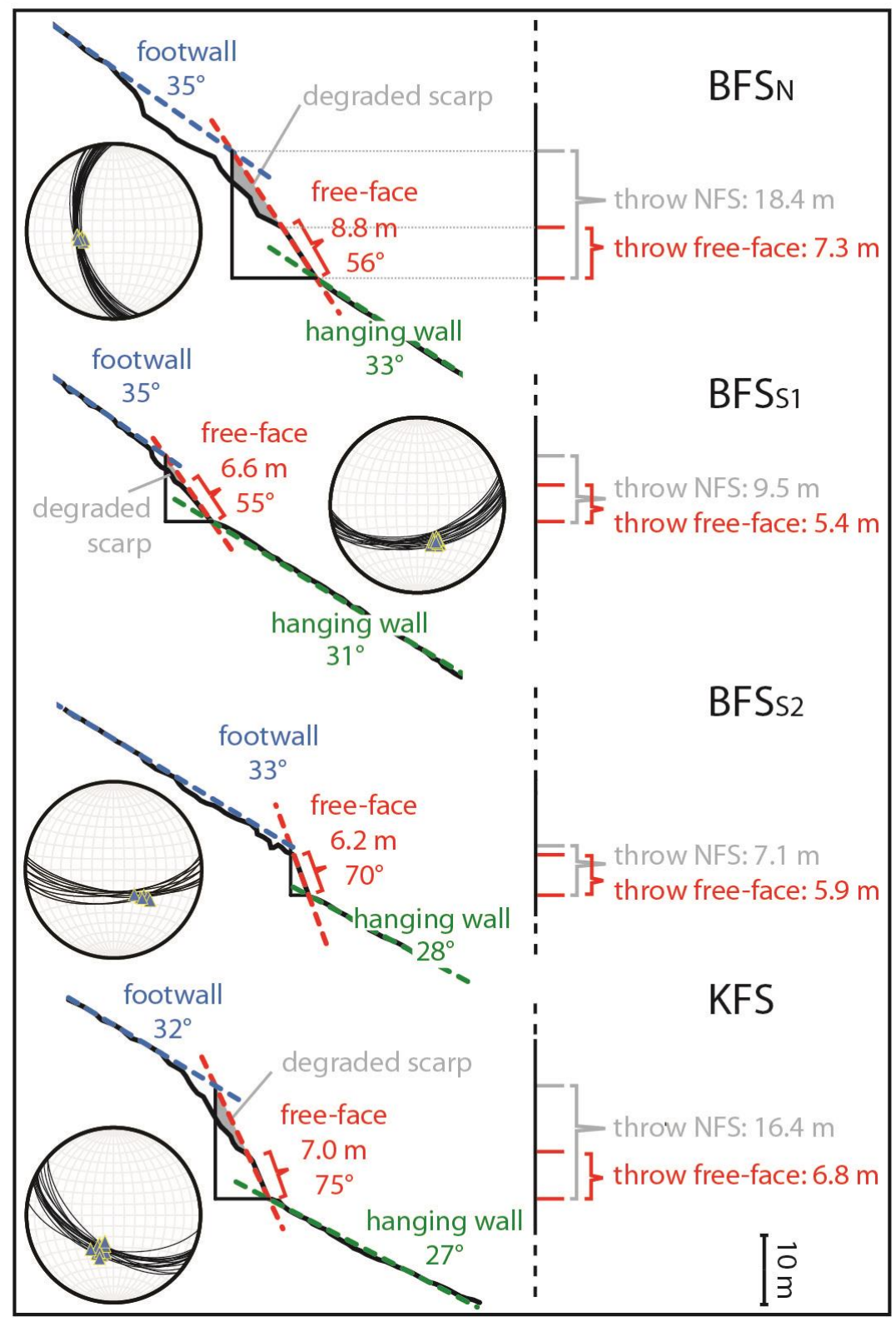

Figure 5: Profiles across the fault scarps at four selected sites (see Fig. 4 for locations). Slip rates are derived from the here presented free-face heights and heights including the degraded scarp (compare Table S10, two right columns). Stereoplots show fault plane orientations (great circles) and striations (triangles) within $\pm 5 \mathrm{~m}$ of the study site. Sites are indicated in Fig. 4; sites BFS $\mathrm{N}$ and BFSs are shown in Figs. $6 \mathrm{~A}-\mathrm{C} \& \mathrm{~S} 2 \mathrm{C}$. 

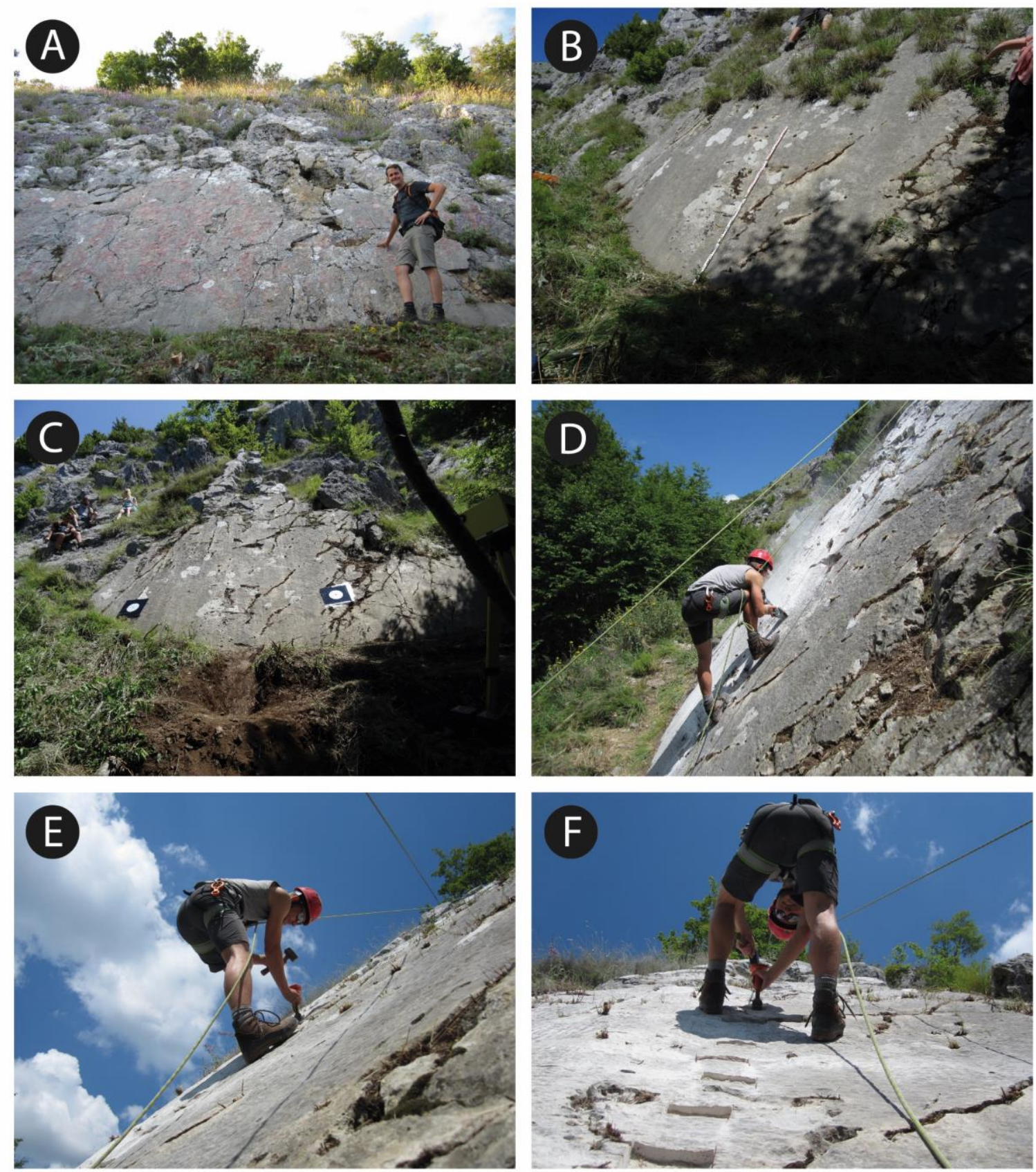

Figure 6: (A) Sampling location BFSs1 as an example where the criterion of a perfectly flat scarp base is met. (B) Difference between

overgrown (top) and cleaned (bottom) fault plane at sampling location BFN $\mathrm{N}_{\mathrm{N}}$. (C) Full view of the cleaned sampling location BFS including a trench below the scarp base. (D-F) Work in progress: Sample blocks are marked and extracted with the help of an angle grinder, hammer and chisel at sampling location BFS $_{\mathrm{N}}$. Image $\mathrm{F}$ shows the trace of extracted sample blocks parallel to striations but avoiding disturbing factors such as joints. 
https://doi.org/10.5194/se-2021-97

Preprint. Discussion started: 6 August 2021

(c) Author(s) 2021. CC BY 4.0 License.
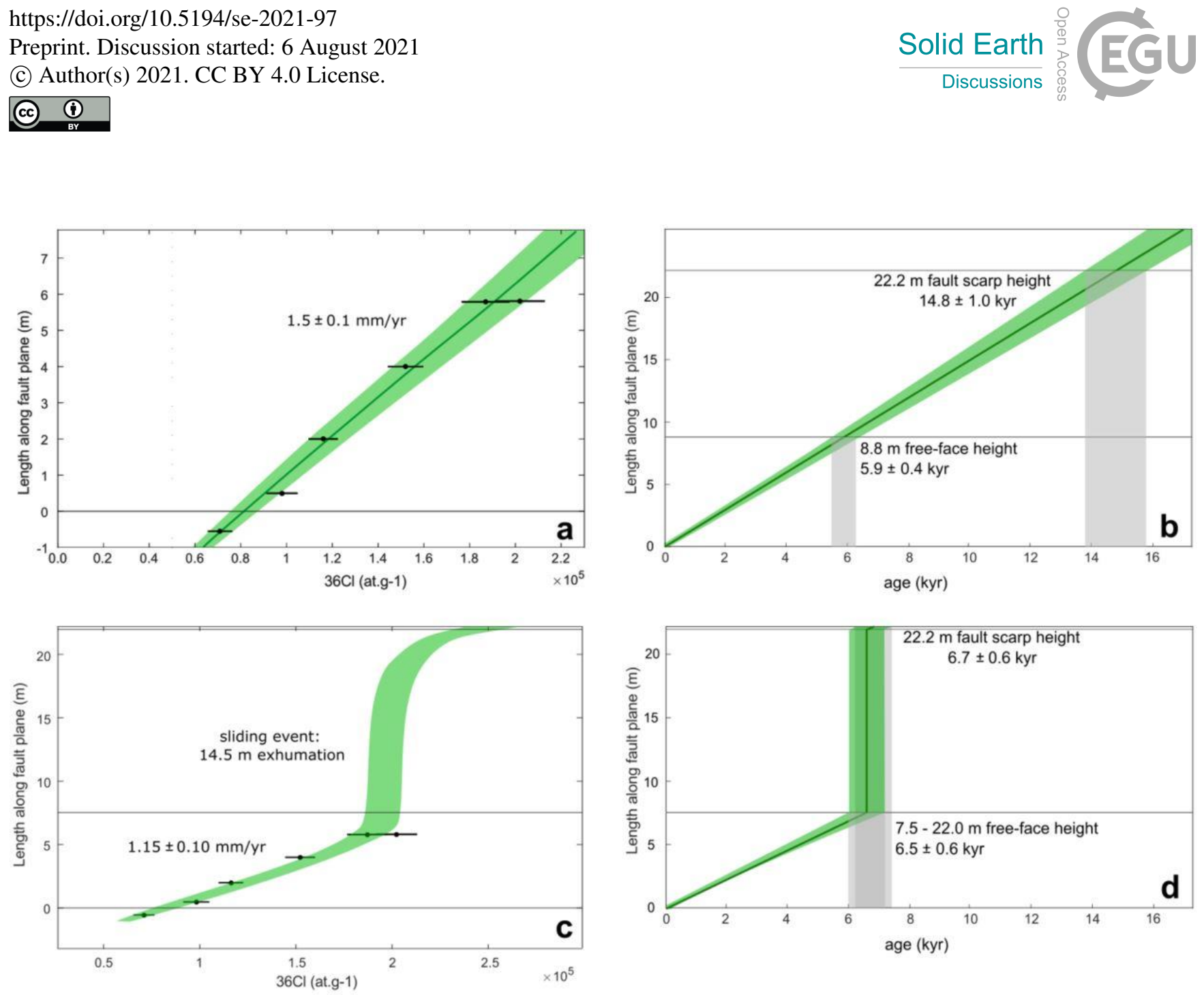

Figure 7: ${ }^{36} \mathrm{Cl}$ concentrations (16 deviations) as a function of the height up the scarp (distance measured on the free-face). (A) Modelled ${ }^{36} \mathrm{Cl}$ concentrations for constant stick-slip rates $(1.5 \pm 0.1 \mathrm{~mm} / \mathrm{yr})$ using the code of Schlagenhauf et al. (2010), with the highest likelihood. (B) The resulting correlation of age and scarp height of (A). (C) Modelled 36Cl concentration for the most likely landslide/rockfall scenario. (D) The resulting correlation of age and scarp height of (B). 
https://doi.org/10.5194/se-2021-97

Preprint. Discussion started: 6 August 2021

(c) Author(s) 2021. CC BY 4.0 License.

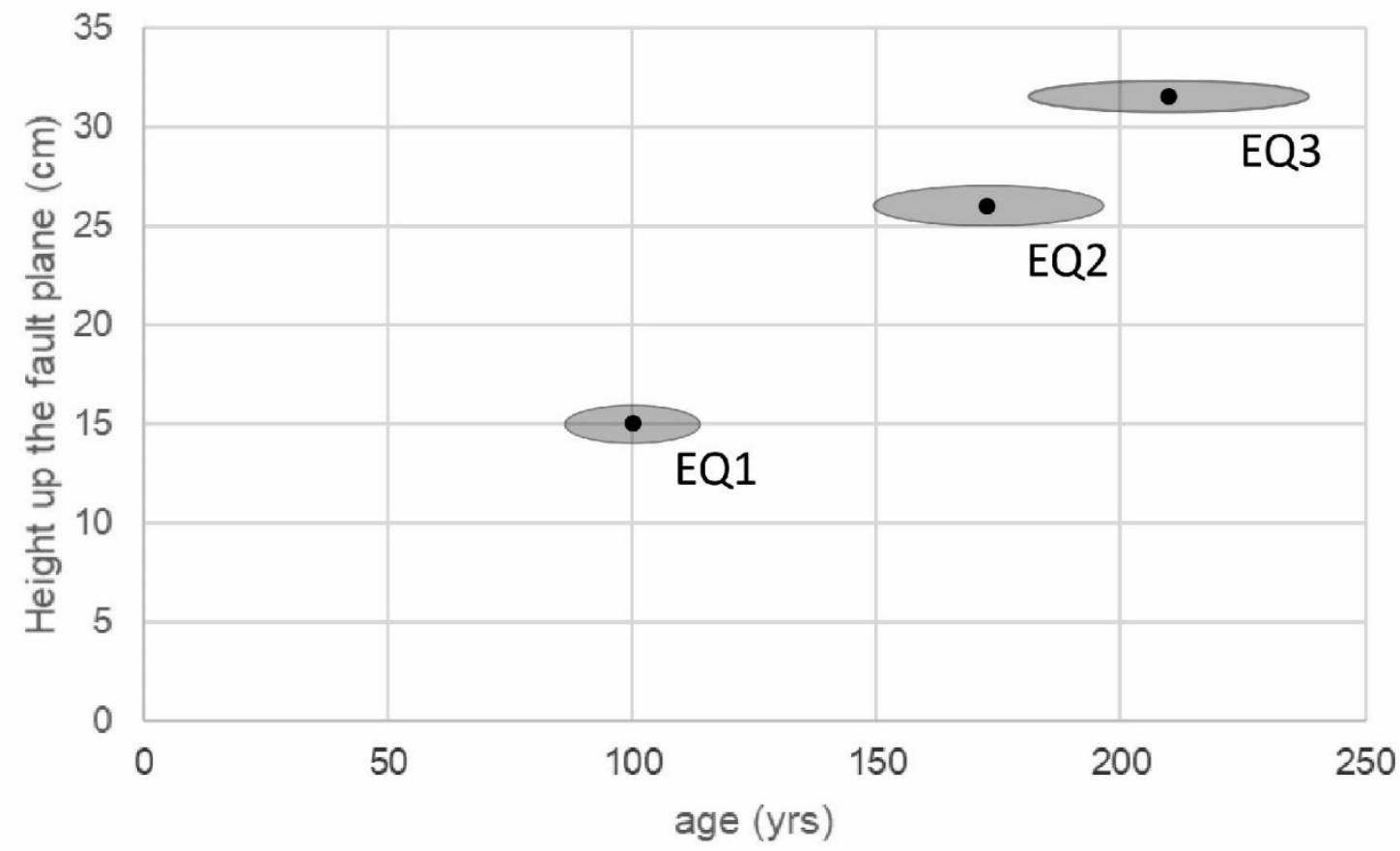

Figure 8: The exhumation history of the free-face at site $\mathrm{BFS}_{\mathrm{N}}$ based on the modeling results (see Fig. 7 A \& B). The slip rate of $1.7 \pm 0.1 \mathrm{~mm} / \mathrm{yr}$ together with the coseismic amount of offset based on the mapped earthquake horizons results in earthquake ages of $100 \pm 14$ yrs (EQ1), $173 \pm 24$ yrs (EQ2) and $210 \pm 29$ yrs (EQ3). All values are given within $68 \%$ (1 sigma) confidence interval. 

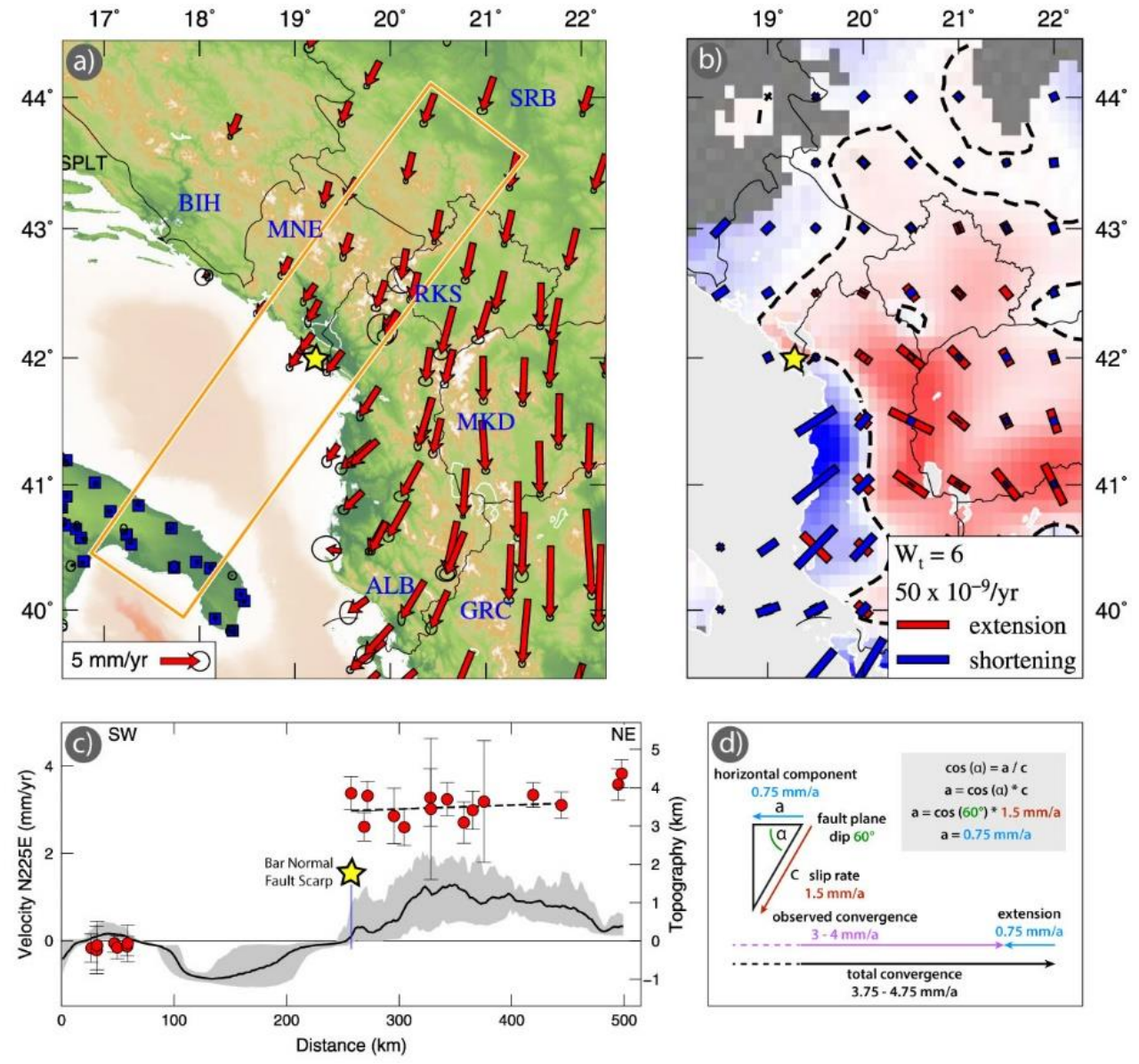

Figure 9: (a) Apulia referenced GPS velocity field and (b) interpolated strain rate with a Gaussian/Voronoi cell weighting of a net reweighting threshold of $W_{t}=6$ in the southwestern Balkans. (c) Swath topographic section with GPS velocity information through the working area. Figures (a)-(c) modified after and reprinted with permission from D'Agostino et al., 2020, see their work for details. (d) Normal faulting related horizontal velocity component and its accelerating role in cross-regional convergence. 
https://doi.org/10.5194/se-2021-97

Preprint. Discussion started: 6 August 2021

(c) Author(s) 2021. CC BY 4.0 License.

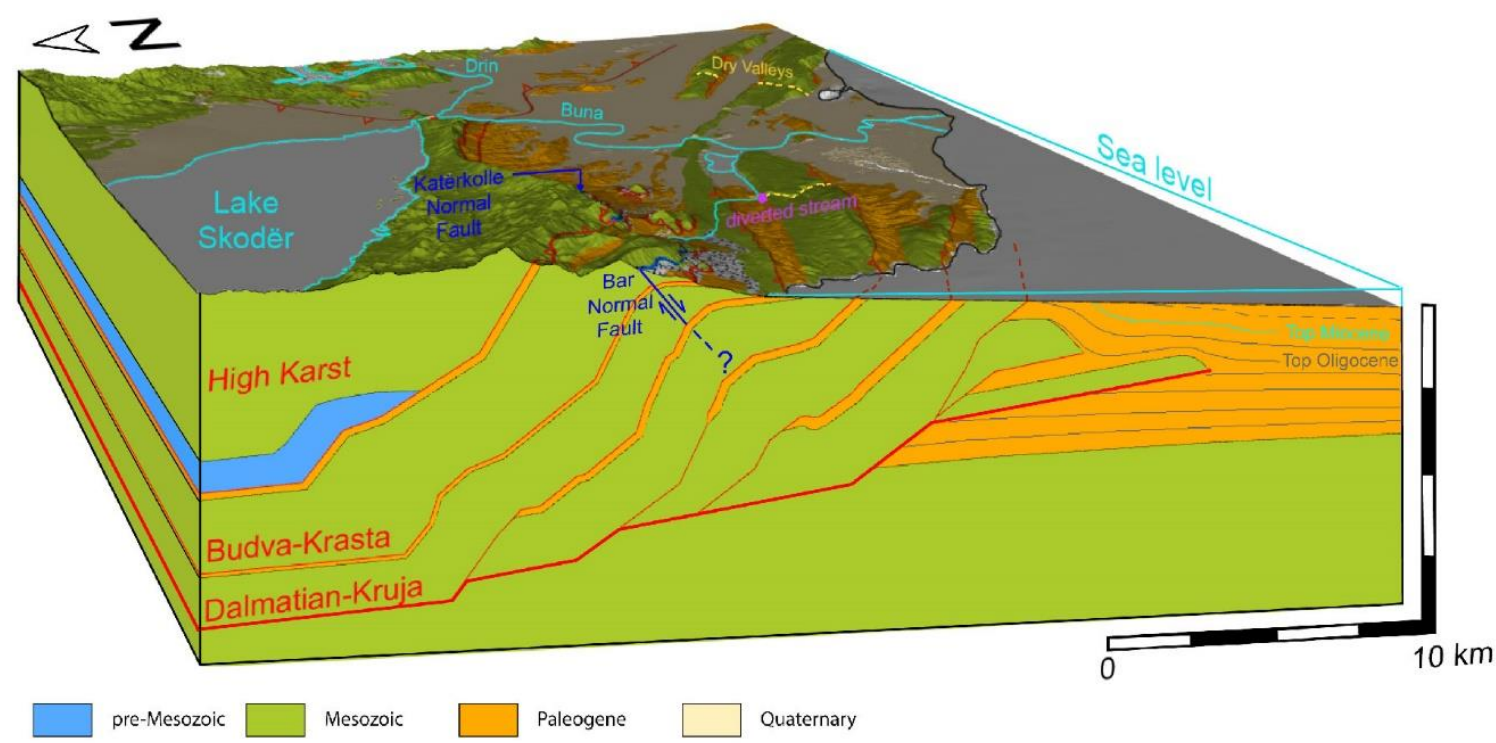

Figure 10: 3D block diagram of the tectono-morphological features of the Montenegro-Albanian coastal border region. Forward modelled structural cross section through the external Dalmatian nappe stack, modified after Schmitz et al. (2020). The spatial proximity of the extensional NFS and contractional dry valleys as well as a supposedly tectonically deviated stream (Biermanns et al. 2019, Schmitz et al. 2020) supports the conclusion of highly interactive tectonic regimes. 